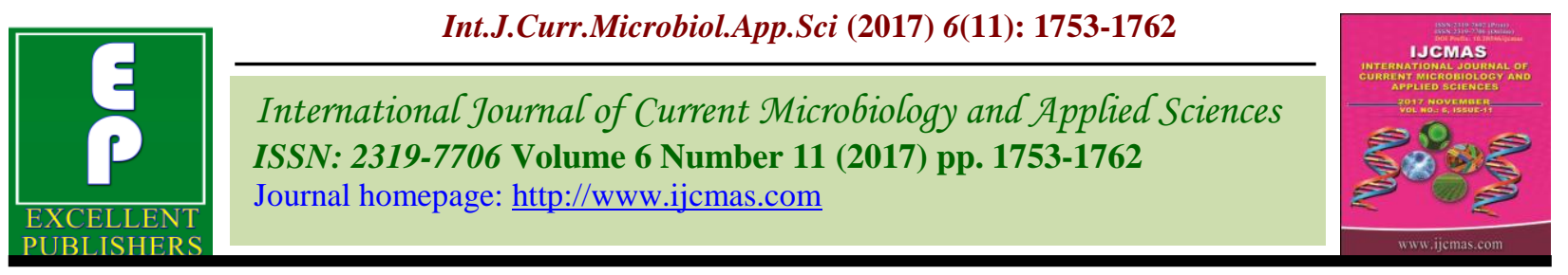

Original Research Article

https://doi.org/10.20546/ijcmas.2017.611.211

\title{
Recreational Value of Wetlands: The Case of Kuttanad Coastal Wetland Ecosystem of Kerala, India
}

\author{
C. Sulakshana Rao $^{1^{*}}$ and R. Balasubramanian ${ }^{2}$ \\ ${ }^{1}$ Department of Agricultural Economics, Tamil Nadu Agricultural University, \\ Coimbatore-641003, Tamil Nadu, India \\ ${ }^{2}$ Department of Market Extension, Tamil Nadu Agricultural University, \\ Coimbatore, Tamil Nadu, India \\ *Corresponding author
}

\begin{tabular}{|c|c|}
\hline & A B S T R A C T \\
\hline $\begin{array}{l}\text { Wetland valuation, } \\
\text { Travel Cost Method, } \\
\text { Trip Generating } \\
\text { Function, Consumer } \\
\text { Surplus. }\end{array}$ & \multirow{3}{*}{$\begin{array}{l}\text { Kuttanad wetlands and the backwaters of Kerala are well recognised for their tourism } \\
\text { amenities at global level. Tourists from across the world visit the backwaters and consume } \\
\text { the recreational benefits provided by the ecosystem. It is a public site, offering the } \\
\text { aesthetic services on a free of cost basis. This study attempts to estimate the recreational } \\
\text { value of the wetland using the travel cost method. The data were collected from a sample } \\
\text { of } 120 \text { visitors using structured questionnaire. The empirical analysis was done by trip } \\
\text { generating function using count data Poisson model. The sign and significance of travel } \\
\text { cost variable (-0.0013) was consistent with the economic theory. Other variables which } \\
\text { significantly affect the dependent variable are family income and site quality. The } \\
\text { consumer surplus per year was estimated to be Rs. } 769.23 \text { by finding the absolute value of } \\
\text { the reciprocal of the travel cost coefficient. The total recreational value of the wetlands per } \\
\text { annum was estimated to be Rs. } 23.57 \text { crores. This huge value of the recreational benefits } \\
\text { emphasizes the need for sustainable management and conservation of the wetlands. }\end{array}$} \\
\hline Article Info & \\
\hline $\begin{array}{l}\text { Accepted: } \\
\text { 15 September } 2017 \\
\text { Available Online: } \\
10 \text { November } 2017\end{array}$ & \\
\hline
\end{tabular}

\section{Introduction}

Wetlands are diverse and productive ecosystems with ecological and economic values (Brander et al., 2006). The RAMSAR convention on wetlands defines wetlands very broadly as: 'areas of marsh, fen, peatland or water, whether natural or artificial, permanent or temporary, with water that is static or flowing, fresh, brackish or salt, including areas of marine water the depth of which at low tide does not exceed six metres'.

Wetlands are valuable and ecologically sensitive systems that occupy about $6 \%$ of the world's land surface (Turner et al., 2000). They comprise both land ecosystems that are strongly influenced by water, and aquatic ecosystems with special characteristics due to shallowness and proximity to land (Roggeri 1995). Wetlands exhibit enormous diversity according to their genesis, geographical location, water regime and chemistry, dominant species, and soil and sediment characteristics (Space Applications Centre, 2011). They also play a significant role in delivering ecosystem services globally. According to Millennium Ecosystem 
Assessment (2005), the services provided by an ecosystem have been categorised into provisioning, regulating, supporting and recreational services. Recreational values contribute a major share to total direct values of wetlands. Although they are recognized and estimated by planners and policy makers in the developed countries for designing appropriate price mechanisms and rules that regulate access, very few attempts have been made in developing countries to recognize and estimate these values. Many of these countries follow a free-access policy to promote international leisure industry, which consolidates the largest proportion of such values generated. The estimation of recreational values of backwaters is, therefore, a necessary pre-condition to understand their economic significance.

Kuttanad wetlands are a public site, offering aesthetic services on a free of cost basis. Many local and foreign tourists visit the backwaters and consume the recreational benefits provided by the ecosystem. Different types of boating facilities are offered namely the backwater trips, estuary sunset rides, canoeing, paddle and pedal boats, houseboats and speed boats. A large population spends time along the banks of the backwaters enjoying its aesthetic beauty. The backwater environment is also used for different purposes such as jogging, recreation, for hosting cultural and religious events, boat races and other festivities. These boat services are supplied by both Government and private enterprises.

The state welcomes large number of both national and international tourist every year. Kuttanad wetlands and the backwaters are the major tourist destination from people across the world. The visitors to Kuttanad backwaters comprise both local and foreign visitors on single or multi-destination trips. Domestic visitors are mainly from the southern states of Tamil Nadu, Karnataka and Telangana as well as from the northern states like New Delhi, Chandigarh, Maharashtra, and Uttar Pradesh. Almost 80 per cent of the tourist arrival is domestic. United Kingdom, Germany and France are the major countries from which foreign tourist arrive. Maximum tourist inflow is during December to March ever year. The amount of tourist visit is also higher during the August month during which the famous Nehru Trophy Boat race is held at the Punnamada lake of Alleppey.

The major attraction of Kuttanad is boating in backwaters and the experience of houseboat stays. Besides this, the tourists, especially the foreign tourists are interested in farm stays in villages. Majority of the tourist are visiting the place for the recreational services and the serene nature of the wetland. The tourists are aware of the ecosystem services provided by the wetlands and have much concern towards the sustainable use of the wetlands. Majority of the public or tourists identify the lack of sanitation and poor water quality of the wetlands as the major issue. The stakeholders are also willing to pay for the conservation efforts and are willing to visit the wetlands more often to avail the ecological benefits of the wetlands. The relevance of Kuttanad wetlands in tourism is very high and it is one of the world famous tourist spot. In this context, the present study was conducted to estimate the recreational value of the Kuttanad wetlands using individual travel cost method approach.

\section{Materials and Methods}

In order to fulfill the objectives of the study, necessary primary data were obtained from the sample respondents by the personal interview method, using a pre-tested and structured schedule.The method of personal interview was adopted to ensure that the data obtained from the respondents were relevant, 
comprehensive and reasonably correct and precise. The interview schedule comprised of three parts: Part I dealt with socio-economic status, occupation and other basic information about the respondents. Part II was stakeholder-specific, in which separate schedules were prepared for the tourist group to cover the number of trips per respondent. The Part III was concerned with qualitative aspects. The valuation part of the schedule was developed by referring the online sources such as The Economics of Ecosystems and Biodiversity (TEEB) and reports of South Asian Network for Environmental Economics (SANDEE) and Technical Report on Economic Valuation of Wetlands (Ramachandra and Rajinikanth, 2005). Data collection was done at the tourist boat hub at Alleppey. A random sample of 120 respondents was surveyed at 7 am to $5 \mathrm{pm}$ during December 2016 and January 2017. The list of tourist visitors was taken from the District Tourism Promotion Council, Alleppey branch in the boat hub area.

\section{Tools and techniques}

Recreational values are reflected in the perceptions of individuals who visit the site by spending time and/or money on recreational activities in the backwaters. Many of these benefits provided by wetlands are not traded in conventional markets and so estimates of their value are not easily and directly obtained. Moreover, people who use the site's resources do not pay for these services and hence it is impossible to use market prices directly to value these recreational benefits provided by the site.

Hence, a surrogate market/ revealed preference method was used to value the recreational benefits. Individual Travel cost method was used in the present study to estimate the value of the Kuttanad wetlands by using a trip generating function.
Recreation benefits of Kuttanad wetlands were estimated using the Travel cost model. The travel cost method for valuing an environmental good was developed under the assumption that there is a weak complementary relationship between the demand for the environmental good and the private good travel. It was assumed that the individuals utility depends on the total time spent at the site, the quality of the site and the quantity of private good other than travel consumed (Clawson and Knetch, 1966; Willis and Garrod, 1991; Bockstael, 1995; Turpie et al., 2001; Turpie and Joubert, 2001). The time spent on the site can be represented by the number of visits. By observing how visitation rates to a site change, as the environmental quality of the site changes, the method also provides values for environmental quality itself. The fundamental insight that drives this model is that if a consumer wants to use the recreational services of a site he has to visit it.

The travel cost to reach the site is considered as the implicit or the surrogate price of the visit, and changes in the travel cost will cause a variation in the quantity of visits. The Individual Travel Cost Method (ITCM) would be used here. The visitors to sites are invited to provide information on the trip (cost, length, purpose, other sites visited, etc.) as well as on other socio-economic features (income, age, sex, etc.). Then the dependent variable is defined as the visitor rate (the number of visits made by the individual in a period).

In mathematical terms the trip demand curve will be defined as:

$V_{i j}=f\left(C_{i j}, X_{i}\right)$

Where:

$\mathrm{V}_{\mathrm{ij}}=$ number of visits made by year by individual $\mathrm{i}$ to site $\mathrm{j}$; 
$\mathrm{C}_{\mathrm{ij}}=$ visit cost faced by individual $\mathrm{i}$ to visit site $\mathrm{j}$;

$X_{\mathrm{i}}=$ all other factors determining individual

i's visits (income, time, and other socioeconomic characteristics).

\section{The empirical model}

$\operatorname{lnV}=\alpha+\beta_{1} \mathrm{AGE}+\beta_{2}$ EDUC $+\beta_{3} \mathrm{FINC}+\beta_{4}$ FAMSIZE $+\beta_{5}$ TRAVCO $+\beta_{6}$ SQLTY,

Where

$\mathrm{V}=$ Number of visits made by individual per year

$\mathrm{AGE}=$ Age of the respondent

$\mathrm{EDUC}=$ Education

TRAVCO = Individual total cost of visiting the site (Rs.)

FINC $=$ Income of the household (Rs./year)

FAMSIZE $=$ Family size

SQLTY $=$ Site quality

Consumer surplus was estimated by the method used in Adamowicz et al., (1989).

$\mathrm{CS}=1 / \beta_{5}$

Where,

$\mathrm{CS}=$ Consumer surplus per visitor (Rs.) $\beta_{5}=$ Estimated co-efficient of travel cost

Total recreational value in Kuttanad wetlands is calculated using the formula,

$V_{R}=C S^{*} V_{n}$

Where,
$V_{R}=$ Value of recreational services (Rs. per annum)

$C S=$ Consumer surplus per visitor (Rs.)

$V_{n}=$ Number of visitors per annum

\section{Results and Discussion}

The tourists or the general public are those stakeholders who reside away from the wetlands and visit the place for the different services. They have no direct dependence on the wetland ecosystem. The occupational activities of this stakeholder group are diverse and it may or may not be dependent on the wetlands. This group represents the society in general and incudes various Government and private employees along with the students, scientists, businessmen, photographers etc. Majority of the stakeholders are from various parts of the country while some are from foreign countries.

Kerala is a state which is known for the natural aesthetics and tourism. The state welcomes large number of both national and international tourist every year. Kuttanad wetlands and the backwaters are the major tourist destination from people across the world. Maximum tourist inflow is during December to March ever year (Figure 1). Almost 80 per cent of the tourist arrivals are domestic tourists (Figure 2). United Kingdom, Germany and France are the major countries from which foreign tourists arrive (Figure 3 ). The amount of tourist visit is also higher during the August month during which the famous Nehru Trophy Boat race is held at the Punnamada lake of Alleppey.

The major attraction of Kuttanad is boating in backwaters and the experience of houseboat stays. Besides this, the tourists, especially the foreign tourists are interested in farm stays in villages. Majority of the tourist are visiting 
the place for recreational activities due to the serene nature of the wetland. The tourists are aware of the ecosystem services provided by the wetlands and have much concern towards the sustainable use of the wetlands.

Majority of the public and tourists identify the lack of sanitation and poor water quality of the wetlands as the major issue. The stakeholders are also willing to pay for the conservation efforts and are willing to visit the wetlands more often to avail the ecological benefits of the wetlands.

The socio-economic profiles of the tourists arrived in Kuttanad area are given in Table 1. The average age of the respondents was 36 . Almost 41.7 per cent of the respondents belonged to the age group of 35-50. The number of respondents belonging to the age group 50-65 was 33 (27.5 per cent). About 28 per cent of the total sample was less than 35 years of age, while remaining 2.5 per cent were of age greater than 65. The level of education of the tourists was also analysed based on the number of years of schooling.
From among the 120 sampled visitors, 3.4 per cent had less than 10 years of schooling. 55 per cent of the sampled respondents were professional degree holders with 15 to 17 years of schooling. A total of 28.3 per cent of the tourists were higher degree holders. The average family size of the stakeholders was three. More than three-fourth of the sample respondents has less than four members in their family, while 17.5 per cent of the respondents have a family size of 4-6. Only six of the respondents have more than six members in the family.

The occupational status of the sampled respondents is given in Table 2. Majority of the sampled respondents were private employees (39.2 per cent). Out of the 120 sample respondents 42 respondents (35 per cent) were Government employees. Other notable occupations were business ( 7.5 per cent), wage labourer (3.3 per cent), and professionals (1.7 per cent). Eleven of the respondents were students and two were housewives constituting 9.2 per cent and 1.7 per cent of the total sample respectively.

Table.1 Socioeconomic details of tourists at Kuttanad wetlands

\begin{tabular}{|c|c|c|}
\hline Socio-economic factors & Number of Respondents & Percentage \\
\hline \multicolumn{2}{|c|}{ I Distribution of Age (years) } \\
\hline 35 & 34 & 28.3 \\
\hline $35-50$ & 50 & 41.7 \\
\hline $50-65$ & 33 & 27.5 \\
\hline$>65$ & 3 & 2.5 \\
\hline Total Average age =36 & $\mathbf{1 2 0}$ & $\mathbf{1 0 0}$ \\
\hline $1-7$ & \multicolumn{2}{|c|}{} \\
\hline $8-10$ & 2 & 1.7 \\
\hline $10-12$ & 5 & 1.7 \\
\hline $12-15$ & 11 & 4.2 \\
\hline $15-17$ & 66 & 9.2 \\
\hline Professional & 34 & 55 \\
\hline Total & $\mathbf{1 2 0}$ & 28.3 \\
\hline \multicolumn{2}{|c|}{ III Size of Family (Number) } & $\mathbf{1 0 0}$ \\
\hline $4-6$ & 93 & 77.5 \\
\hline$>6$ & 21 & 17.5 \\
\hline & 6 & 5 \\
\hline Total Average family size=3 & $\mathbf{1 2 0}$ & $\mathbf{1 0 0}$ \\
\hline
\end{tabular}


Table.2 Details of the occupational status of the respondents

\begin{tabular}{|c|c|c|c|}
\hline Sl no: & Occupation & No. of respondents & Percentage \\
\hline 1 & Labourer & 4 & 3.3 \\
\hline 2 & Private job & 47 & 39.2 \\
\hline 3 & Government job & 42 & 35.0 \\
\hline 4 & Business & 9 & 7.5 \\
\hline 5 & Student & 11 & 9.2 \\
\hline 6 & Pensioner & 3 & 2.5 \\
\hline 7 & Professionals & 2 & 1.7 \\
\hline 8 & House-wife & 2 & 1.7 \\
\hline & Total & $\mathbf{1 2 0}$ & $\mathbf{1 0 0}$ \\
\hline
\end{tabular}

Table.3 Details of annual family income

\begin{tabular}{|c|c|c|c|}
\hline Sl no & Income (Rs. Lakh/year) & No. of respondents & Percentage \\
\hline 1 & $1-2$ & 3 & 2.5 \\
\hline 2 & $2-4$ & 27 & 22.5 \\
\hline 3 & $4-6$ & 79 & 65.8 \\
\hline 4 & $>6$ & 11 & 9.2 \\
\hline & Total & $\mathbf{1 2 0}$ & $\mathbf{1 0 0}$ \\
\hline
\end{tabular}

Table.4 Parameter estimates of trip generating function

\begin{tabular}{|c|c|c|}
\hline Variable & Coefficient & p-value \\
\hline Constant & $0.125(0.123)$ & 0.311 \\
\hline AGE $\left(\beta_{1)}\right.$ & $0.0002(0.0016)$ & 0.894 \\
\hline EDUC $\left(\beta_{2}\right)$ & $0.0078(0.0066)$ & 0.245 \\
\hline FAMSIZE $\left(\beta_{3)}\right.$ & $0.017 * *(0.0082)$ & 0.04 \\
\hline FINC $\left(\beta_{4}\right)$ & $0.00002(0.00003)$ & 0.498 \\
\hline SQLTY $\left(\beta_{5)}\right.$ & $0.085^{* * *}(0.024)$ & 0.001 \\
\hline TRAVCO $\left(\beta_{6}\right)$ & $-0.0013^{*} * *(0.00034)$ & 0.000 \\
\hline & \multicolumn{2}{|c|}{ Log likelihood $=97.28$} \\
\hline
\end{tabular}

Source: Primary survey and authors own estimation

Note: $* * * * *$ and $*$ implies significance at $1 \%, 5 \%$ and $10 \%$ respectively.

Standard errors are presented in Parenthesis

Table.5 Recreational value of Kuttanad wetlands

\begin{tabular}{|l|c|}
\hline \multicolumn{1}{|c|}{ Particulars } & Value \\
\hline Consumer surplus per visit & 769.23 \\
\hline No. of visitors per year & 306493 \\
\hline Total consumer surplus & 235763846 \\
\hline Recreational value per annum (in Rs. Crores) & 23.57 \\
\hline
\end{tabular}


Fig.1 Month-wise arrival of tourists to backwaters (2014)

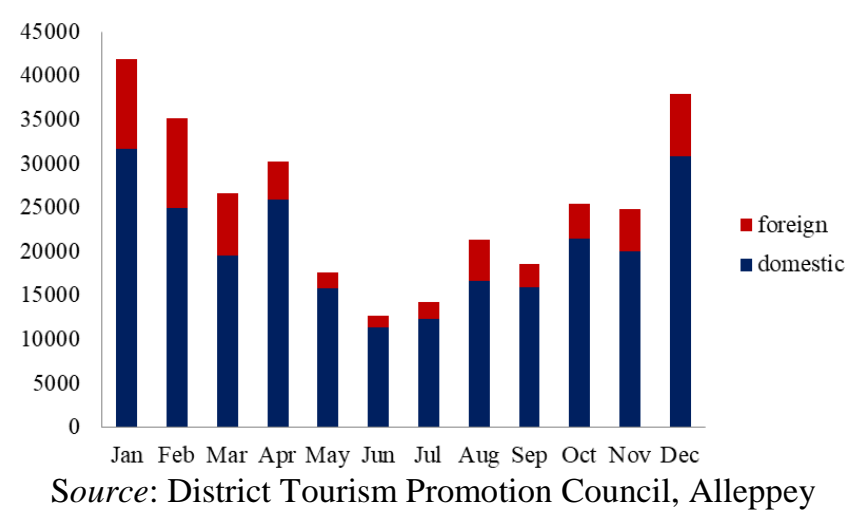

Fig.2 Tourist arrival at Backwaters: Foreign Vs Domestic

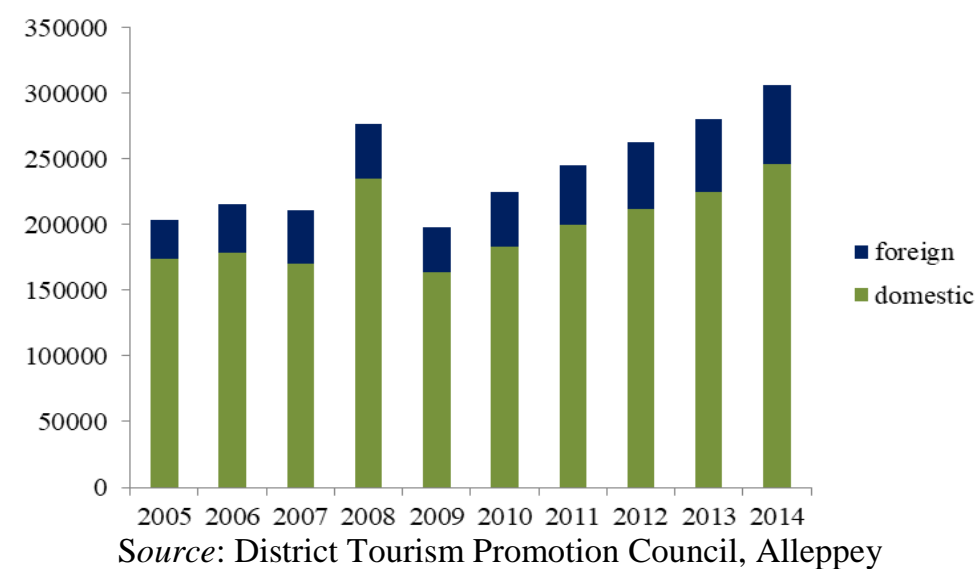

Fig.3 Country wise foreign tourist arrival (2014)

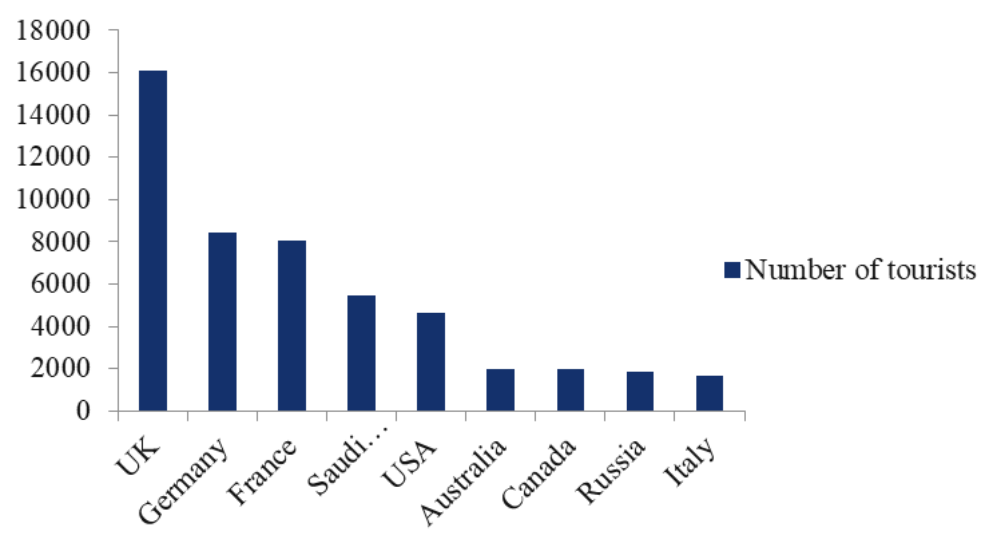

Source: District Tourism Promotion Council, Alleppey

The details regarding annual family income of the tourists is shown in Table 3. Since, majority of the public were professional degree holders and employed in various private firms, the level of income of the tourists was higher than the rest of the stakeholders. About 66 per cent of the total respondents belonged to the income category 
of 4-6 lakhs per year, followed by 27 of the respondents (22.5 per cent) between 2-4 lakhs per annum. Almost 10 per cent of the total respondents had more than six lakh per annum of household income. On the other hand 2.5 per cent of the household had an annual family income less than a lakh.

\section{Results of travel cost analysis}

The log-linear trip generating function was formulated using number of visits per year as dependent variable. The independent variables were socio-economic variables, travel cost and the quality of site.

The estimated trip generation function is summarised in Table 3 . The signs of the coefficients were in consistence with the economic theory. The independent variables that significantly affect the trip generating function are travel cost (negative effect), family size (positive effect) and site quality (positive effect). The negative sign of the travel cost and the significance of the travel cost at one per cent level of significance are in accordance with the results of Anoop et al., 2008 and Vijayan \& Job (2015). The negative sign of the travel cost indicates that the number of visits to the ecosystem decreases as travel cost increases. Other variables which significantly affect the dependent variable are family income and site quality.

The consumer surplus could be estimated by finding the absolute value of the reciprocal of travel cost coefficient. The consumer surplus is the surrogate value of net social benefit received from the ecosystem. The consumer surplus per visit was estimated to be Rs. 769.23 (Table 5).

The total recreational value of the wetlands was obtained by multiplying the total number of visitors by the consumer surplus per visit. The estimated total recreational value was Rs.
23.57 crores. Similar studies were conducted in Kerala, India and abroad to determine the recreational value of lakes and wetlands. The recreational value of Cochin backwaters was estimated using the zonal travel cost method by Abraham (2006) and the value was estimated to be Rs.3.81 crores. Anoop et al., (2008) estimated the value of Astamudi Lake in Kerala to be Rs. 0.15 crores using travel cost method which is less than the estimated value of the Kuttanad wetlands. Another study in Kerala by Vijayan and Job (2015) estimated the recreational value of Vellayani Lake in Trivandrum to be 0.55 crores. Dehalavi and Adil (2011) also applied travel cost method to estimate the recreational value of Keenjhar Lake in Pakistan to be $\$ 4.2$ crores.

Kuttanad wetlands provide direct and indirect recreational befits to both domestic and foreign visitors. However, most of the recreational benefits provided by wetlands do not have markets and hence the value of the recreational service it provides is often discounted to zero. Similarly, in most estimates of the direct benefits provided by the wetlands, recreational values are not included. Hence the value of the wetlands is often underestimated.

Hence, this study attempted to estimate the recreational value of Kuttanad wetlands using the surrogate market/ revealed preference approach by using the individual travel cost method. The total recreational value of the wetlands was estimated to be Rs. 23.57 crores. But it must be remembered that all this value are provided by the wetlands free of cost. So it is imperative that the recreational services are promoted as well as conserved without deteriorating the quality of the ecosystem.

The recreational services provided by Kuttanad wetlands do not have markets and 
hence are not valued effectively. Because of this, the real economic value of the wetlands is under estimated. This leads to undervaluation of the wetland resource management and conservation activities. Ultimately, the different ecological services would be over-utilized and would be lost. In general, if there is no proxy of economic value of natural resources, it is apparently difficult to generate sustainable benefit from the resource and difficult to allocate it based on the efficient economic criteria. Hence, this study estimated the recreational value of Kuttanad wetlands using the surrogate market/ revealed preference approach by using the individual travel cost method. The total recreational value of the wetlands was estimated to be 23.57 crores. This huge value of the recreational benefits emphasizes the need for sustainable management and conservation of the wetlands.

\section{Acknowledgment}

The author whole-heartedly acknowledges the timely fellowship support provided by Department of Science and Technology: Innovation in Science Pursuit for Inspired Research (DST-INSPIRE) during the Ph.D. Programme.

\section{References}

Adamowicz, W., Louviere, J., and Williams, M. (1994). Combining revealed and stated preference methods for valuing environmental amenities. Journal of environmental economics and management, 26(3), 271-292.

Anoop, P., and Suryaprakash, S. (2008, August). Estimating the option value of Ashtamudi Estuary in South India: A contingent valuation approach. In International Congress of European Association of Agricultural Economists, Ghent, Belgium.
Bockstael, N., Costanza, R., Strand, I., Boynton, W., Bell, K., and Wainger, L. (1995). Ecological economic modeling and valuation of ecosystems. Ecological economics, 14(2), 143-159.

Brander, L. M., Florax, R. J. G. M., and Vermaat, J. A. N. E. (2006). The Empirics of Wetland Valuation: A Comprehensive Summary and a MetaAnalysis of the Literature, 223-250. http://doi.org/10.1007/s10640-0053104- 4

Dehlavi, A., and Adil, I. H. (2011). Valuing the recreational uses of Pakistan's wetlands: an application of the travel cost method. SANDEE.

Hellerstein, D., and Mendelsohn, R. (1993).A theoretical foundation for count data models. American journal of agricultural economics, 75(3), 604-611.

Loomis, J., Yorizane, S., and Larson, D. (2000). Testing significance of multidestination and multi-purpose trip effects in a travel cost method demand model for whale watching trips. Agricultural and Resource Economics Review, 29(2), 183-191.

Millennium Ecosystem Assessment (MEA), 2005. Ecosystems and Human Wellbeing: Wetlands and Water Synthesis. World Resources Institute, Washington, DC.

Ramachandra, T. V., Rajinikanth, R., and Ranjini, V. G. (2005). Economic valuation of wetlands. Journal of Environmental Biology, 26(2), 439.

Roggeri, H. 1995. Tropical Freshwater Wetlands: A Guide to Current Knowledge and Sustainable Management. Developments in Hydrobiology 112. Kluwer Academic Publishers, Dordrecht 363pp.

Shaw, W. D. (1992). Searching for the Opportunity Cost of an Individual's Time. Land Economics, 107-115. 
Space Applications Centre (SAC), 2011. National Wetland Atlas. SAC, Indian Space Research Organisation, Ahmedabad.

Susan, A., and Thomson, K. T. (2006). Economic Valuation of Coastal Wetlands: A Study of Cochin Back waters in Kerala (Doctoral dissertation, Cochin University of Science and Technology).

Turner,R.K., van den Bergh, J.C.M, Soderqvist, T., Barendregt, A., van der Straaten, J., Maltby, E., van Ierland, E.C. (2000) Ecological-Economic Analysis of Wetlands: Scientific Integration for Management and Policy, Ecological Economics, 35, pp. 7-23
Turpie, J., and Joubert, A. (2001).Estimating potential impacts of a change in river quality on the tourism value of Kruger National Park: An application of travel cost, contingent, and conjoint valuation methods. Water $S a, 27(3), 387-398$.

Vijayan, A., Job, E., 2015. Recreational value of Vellayani lake in South India: a travel cost approach. Int. J. Sci. Res. 4 (11), 156-158.

Willis, K. G., and Garrod, G. D. (1991).An individual travel- cost method of evaluating forest recreation. Journal of agricultural Economics, 42(1), 33-42.

\section{How to cite this article:}

Sulakshana Rao, C. and Balasubramanian, R. 2017. Recreational Value of Wetlands: The Case of Kuttanad Coastal Wetland Ecosystem of Kerala. Int.J.Curr.Microbiol.App.Sci. 6(11): 17531762. doi: https://doi.org/10.20546/ijcmas.2017.611.211 